\title{
The Effectiveness of Homelessness and Beggars Handling Related to the Badung Regency Regulation Number 7 of 2016 Concerning Public Order and Peace of the Community
}

\author{
Ni Putu Yunika Sulistyawati ${ }^{1 *}$, Sang Ayu Made Ary Kusumawardhani ${ }^{1}$ \\ Faculty of Law, Dwijendra University, Bali, Indonesia
}

\begin{abstract}
The flow of urbanization to Badung Regency and other cities as it gets bigger as the regional economy develops. On the other hand, the opportunities available and the opportunities to try in the city are not able to accommodate urbanization actors because of the limited skills that have in the home area so as to cause one of the problems is the onsling of homeless people and beggars. The formulation of the problem faced is the effectiveness of tackling homelessness and beggars related to the regulation of badung district number 7 in 2016 on public order and community peace, what is done by the badung district government in dealing with homelessness and beggars? The type of research that the author uses in this study is legal research with empirical aspects. Given the effectiveness of tackling homelessness and beggars related to the Badung regency regional regulation number 7 of 2016 concerning public order and public order. Researchers have conducted field research with interviews and observations in several areas of Badung, Jimbaran, Mengwi, Kapal, Nusa Dua districts and several places in Badung regency. The conclusion is that the factors causing the occurrence of vagrants and beggars. Internal factors include poverty, age, low levels of formal education, parental consent, low levels of skills, mental attitudes, while external factors include; hydrological conditions, agricultural conditions, conditions of infrastructure and physical facilities, access to information and business capital, primitive conditions of urban communities, weaknesses in handling vagabonds and beggars in cities. Based on the research results, the effectiveness of tackling homelessness and beggars related to the Badung regency regional regulation number 7 of 2016 concerning public order and public peace, especially in article 27 point 1 regarding each prohibited from carrying out vagrant and beggar activities, busking and trading hawkers on public vehicles, government offices, road junctions / traffic light, parks owned by local governments, schools, hospitals and health centers have been effective, proven to reduce numbers vagrants and beggars in Badung Regency, the efforts made by the Badung regency government in dealing with homeless people and beggars are by taking preventive measures to prevent homelessness and beggars before the occurrence or occurrence of homelessness and beggars and prevention of repressions including; about Secrets, temporary shelter and delegation.
\end{abstract}

Keywords : Homeless and Beggars

*Corresponding Author:

E-mail: putu_yunika@yahoo.com (Ni Putu Yunika Sulistyawati)

Dwijendra University, Denpasar, Indonesia

\section{INTRODUCTION}

Bali is an area with a thousand temples and tourism objects to become one of the world's destinations, and an island paradise for foreign tourists from different parts of the world. One of the problems that arises is the growing inequality in income sharing between different income 
Journal of Sustainable Develpment Science

Vol. 2, No. 2, December 2020, pp. 53-59

e-ISSN: 2715-9140 | p-ISSN: 2722-919X

groups, between urban and rural areas, this means also that rapid economic growth has not succeeded in tackling poverty problems, such as unemployment and other socio-economic problems, such as homelessness and beggars.

As a result, those who deliberately become homeless and beggars (Gepeng) in cities such as Badung will increasingly become much-needed "figures" because of perceived disturbing order and security on the streets including in some settlements. In general, those who become Gepeng are mostly from Munti Gunung Hamlet in West Tianyar Village, Kubu District, Karangasem Regency.

People in their society tend to develop and experience changes in both their activities and associations. In the development of these changes, they must be guided by the prevailing social norms, namely a series of general provisions or regulations either unwritten or written, about human behavior or actions in accordance with the judgment of the community is considered good or bad, appropriate or inappropriate (Soerdjono D, 1982)

A commandment shows one way that benefits or at least does not harm the common life, and closes another path that may be harmful. So what is formulated in the form of prohibitions are things that must be avoided, because if they are done it will disturb order and peace in society. This is where the law acts as the controller of society, so that they do not violate the norms that are embedded in it written and unwritten legal rules (Soerjono Soekanto ).

Journal Homepage:

http://ejournal.undwi.ac.id/index.php/jsds
In the development of the policy dynamics of laws and regulations, among others, the enactment of Law Number 23 of 2014 concerning Regional Government, Government Regulation Number 6 of 2010 concerning Civil Service Police Units, Regulation of the Minister of Home Affairs Number 54 of 2011 concerning Standard Operating Procedures for Civil Service Police as well as developments sociology and community needs that have not been accommodated in Regional Regulation No. 4 of 2001 concerning Cleanliness and and Public Order, hence the regulation on Public Order and Community Peace in Badung Regency, Badung Regency Regional Regulation No. 7 of 2016 concerning "Public Order and Public Peace".

Given such circumstances, it is not to be waited for anymore, bums and beggars as social problems need to be sought a way out to overcome it. If possible eliminate it altogether. This is the duty of the community with one of its antidotes, is with Government Regulation No. 31 of 1980 on Countering Homelessness and Beggars, and also in badung regency with the local regulation of Badung Regency No. 7 of 2016 on "Public Order and Public Peace" in line with article 34 of the Constitution of the Republic of Indonesia 1945. Contrary to the background of the above issue, then on the issue that will be discussed then the researchers formulate whether the effectiveness of homeless ness and beggars is related to badung district regulation Number 7 year 2016 Public Order and Community Peace, What is done by 


\section{Journal of Sustainable Develpment Science}

Vol. 2, No. 2, December 2020, pp. 53-59

e-ISSN: 2715-9140 | p-ISSN: 2722-919X

badung district government in dealing with homelessness and beggars?

\section{METHODS}

\subsection{Types of Research}

The type of research that the authors use in this research is legal research with empirical aspects. Given that the effectiveness of handling homeless people and beggars related to the Badung Regency Regional Regulation Number 7 of 2016 is still deemed ineffective, this needs special attention so far these cases have always been resolved.

\subsection{Data and Data Sources}

There are two types of data examined in this study, namely primary data and secondary data. Primary data from this study comes from field research which is obtained directly through interviews and observations by respondents and informants. Meanwhile, secondary data is obtained from literature research, literatures. and the Prevailing Laws.

\subsection{Data Collection Techniques}

\subsubsection{Document Study Techniques}

Document studies are an early technique used in every legal science study, which always departs from the normative premise. The initial document used in this study is Badung Regency Regional Regulation No. 7 of 2016.

\subsubsection{Interview Techniques}

The interview technique in this study was carried out by compiling questions that were relevant and related to the effectiveness of handling homeless

Journal Homepage:

http://ejournal.undwi.ac.id/index.php/jsds people and beggars related to the Badung Regency Regional Regulation Number 7 of 2016 Public Order and Community Peace. respondents and informants who have the capacity and are related to the research being carried out. field research with interviews in several districts of Badung, Jimbaran, Mengwi, Kapal, Nusa Dua and several places in Badung regency.

\subsubsection{Observation Techniques}

Observation techniques are needed in this study with the aim of collecting data by directly observing legal incidents involving vagrants and beggars related to the Badung Regency Regional Regulation Number 7 of 2016 Public Order and Peace of the People. field research with observations in several areas of Badung regency, Jimbaran, Mengwi, Kapal, Nusa Dua and several places in Badung regency.

\section{RESULTS AND DISCUSSION}

3.1. What is the effectiveness of homelessness and beggars eradication related to the Badung

Regency Regulation Number 7 of 2016 Public Order and Peace of the Community

Talking about the problems of homelessness and beggars, we must see the limitations of both of these. Before going any further, we should first talk about homelessness, so that we can imagine what is actually meant by homelessness.

The term homeless, as said by W.J.S. Poerwadarminta, that; "The bum comes from the word midfielder which means "adventure", wandering around and walking around does not necessarily mean" (W.J.S. Poerwadarminta, 1979).

Copyright (C) 2020 Dwijendra University. All right reserved. 
Journal of Sustainable Develpment Science

Vol. 2, No. 2, December 2020, pp. 53-59

e-ISSN: 2715-9140 | p-ISSN: 2722-919X

Another term in press publications, is put forward with a new term, namely "homeless", unemployed which means having no home (place to live) and not having a permanent job and his daily life is homeless (Soerjono. D, 1973).

Meanwhile, in the draft law on the shelter of homeless people in Indonesia, Article 1 states that what is meant by homeless people is "people who are adventurous or are stranded because they live in an improper place to live and have an improper livelihood.

Beggars are people who earn their income by begging in public in various ways and reasons to expect mercy from others.

Furthermore, the Regional Office of the Ministry of Social Affairs in the Province of Bali states that "a homeless person is someone who lives in a situation that is not in accordance with the norms of a proper life in society, does not have a permanent residence"'(Simanjuntak, 1981)

In addition, according to simanjuntak in his book entitled Aspects of Social Peratology mentions that: "Homeless people are both male and female individuals, teenagers or children or are families (husbands) who without a living or any work roam in cities without houses, residences are not even registered as local residents".

The Directorate of Social Rehabilitation (Dirjen Bina Rehabilitasi Sosial R.I. in Jakarta) defines homeless people and beggars, among others:

1. Tuna lives in the sense of not having KTP, family card, RW, local RT, places of residence that move around.

2. Do not have a permanent job, they are only seekers for items that are not suitable to be collected, for example cigarette butts, papers , plastics and cans, besides that most also expect mercy by begging in public

3. The place where he lives is uninhabitable, such as under bridges, damaged railroad cars, wild huts, along the riverbanks, shop porches and other open areas.

With the research conducted by researchers, it is hoped that it will be an effort to overcome the problems of homeless people and beggars in Badung Regency.

The Institute for Research and Community Service of the Indonesian Islamic University of Yogyakarta, which takes Field Sampling (field samples) from homeless people in Yogyakarta, divides and classifies the homeless people into 3 groups, including (Noach, Simanjuntak, B. dan Pasaribu, I L., 1984):

1. A homeless person who still wants to hang out with the community;

2. A homeless person who has an organization

3. A homeless person.

One of the goals of job seekers who come from various regions both from Bali and outside Bali. Beggars, what is meant by residing or sleeping on the street is a place to live or sleep on the road either on the road or on the road and under the bridge.
Journal Homepage:

http://ejournal.undwi.ac.id/index.php/jsds
Copyright (C) 2020 Dwijendra University. All right reserved. 


\section{Journal of Sustainable Develpment Science}

Vol. 2, No. 2, December 2020, pp. 53-59

e-ISSN: 2715-9140 | p-ISSN: 2722-919X

Referring to the Badung Regency Regional Regulation Number 7 of 2016 concerning the effectiveness of tackling homeless and beggars related to the Badung district regional regulation number 7 of 2016 concerning public order and public tranquility, especially in article 27 number 1 concerning every prohibited from carrying out homeless and begging activities, singing and trading hawkers on public transportation, government offices, crossroads / traffic lights, parks owned by local governments, schools, hospitals and health centers.

On the basis of this Perda, the Badung Regency Government takes a policy in prosecuting any violations of the regional regulations that have been stipulated so far, so in other words the Government issued a policy prohibiting vagabonds and begging in the Badung Regency area.

After researchers conducted research in the field for several months on several homeless people and beggars in Badung Regency, it was found that the existence of Badung Regency Regional Regulation Number 7 of 2016 Public Order and Peace of the People, in the areas of Mengwi, Jimbaran, Nusa Dua, Kuta, Ships have been proven effective by decreasing the number of vagabonds and beggars in the Badung Regency area, apart from the results of research with interviews and observations of researchers get a lot of information about the factors that cause vagrancy and begging from economic factors, natural factors that do not contribute to their survival, most of them are generally economic hardships from underprivileged family backgrounds who come from barren and dry areas with no source of livelihood.

\subsection{Efforts made by the Badung Regency} Government in dealing with Homeless and Beggars.

The Badung Regency Government continues to strive to improve supervision and control of homeless people and beggars as stated in the Government also aims to provide rehabilitation and skills training to homeless people and beggars who are caught in every raid in order to be able to find a decent life and livelihood as a citizen of the Republic of Indonesia. , and turn them into respectful, preventive members of society widespread influence due to vagabonds and beggars in society.

\subsubsection{Preventive Countermeasures}

Preventive efforts have been adjusted to Badung District Regulation No. 7 of 2016 on "Public Order and Community Peace" which aims to prevent the onset of homelessness and beggars in the community, in order to maintain cleanliness and public order aimed at both individuals and community groups that are thought to be the source of homelessness and beggars.

This preventive effort is to prevent the existence or occurrence of homeless people and beggars, as what the Badung Regency Government has done is by conducting strict supervision of newcomers, holding raids for Identity Cards (KTP), Kipem or domicile documents, and explaining the purpose its existence or the purpose of its arrival to
Journal Homepage:

http://ejournal.undwi.ac.id/index.php/jsds
Copyright (C) 2020 Dwijendra University. All right reserved. 
Journal of Sustainable Develpment Science

Vol. 2, No. 2, December 2020, pp. 53-59

e-ISSN: 2715-9140 | p-ISSN: 2722-919X

Bali Island Generally and particularly in the Badung Regency Government area.

\subsubsection{Repressive Countermeasures}

In this case, the Badung Regency Government has made reformative efforts which include:
a. About the raids
b. About the temporary shelter and
c. About the delegation

The efforts to overcome homelessness and beggars by the Badung Regency Government based on Badung Regency Regional Regulation Number 7 of 2016 concerning "Public Order and Community Peace" have not achieved maximum results, due to several obstacles or obstacles in their implementation.

\section{CONCLUSIONS}

That the factors causing the homelessness and beggars. Internal factors include poverty, age, low levels of formal education, parental consent, low levels of skills, mental attitudes, while external factors include; hydrological conditions, agricultural conditions, conditions of infrastructure and physical facilities, access to information and business capital, primitive conditions of urban communities, weaknesses in handling vagabonds and beggars in cities. Based on research results, effectiveness the prevention of homelessness and beggars related to the Badung regency regional regulation number 7 of 2016 concerning public order and public order, especially in article 27 point 1 concerning each prohibited from carrying out vagrant and beggar activities, busking and trading hawkers on public vehicles, government offices, road junctions / traffic lights, parks owned by local governments, schools, hospitals and health centers have been proven effective in reducing the number of homeless and beggars in Badung district.

The efforts made by the Badung district government in dealing with homeless people and beggars is to take preventive measures by preventing the existence or occurrence of homelessness and beggars and prevention of repressions including; regarding Secrets, temporary shelter and delegation.

\section{Suggestion}

The handling of the problem of Bums and Beggars (Gepeng) in Badung Regency cannot be released from the handling of poverty itself, especially when viewed from the point of view of gepeng's home region. It is recommended to the Badung Local Government to deal with homeless and beggars by doing preventive countermeasures by preventing the absence or the onsling of bums and beggars and refresif prevention includes ;about Secrets, Temporary Shelters and Impeachment.

\section{REFFERENCE}

Direktorat Rehabilitasi Sosial (Dirjen Bina Rehabilitasi Sosial RI di Jakarta), 1987, Petunjuk Teknik Penanggulangan Gelandangan dan Pengemis.

Noach, Simanjuntak, B. dan Pasaribu, I L., 1984, Kriminologi, Tarsito Bandung,

Peraturan Pemerintah Nomor 31 tahun 1980, Tentang Penanggulangan Gelandangan dan Pengemis, Biro Humas Depsos, RI.
Journal Homepage:

http://ejournal.undwi.ac.id/index.php/jsds
Copyright (C) 2020 Dwijendra University. All right reserved. 
Journal of Sustainable Develpment Science

Vol. 2, No. 2, December 2020, pp. 53-59

e-ISSN: 2715-9140 | p-ISSN: 2722-919X

Poerwadarminta, W.J.S. 1985, Kapita Selecta Kriminologi, Alumni, Bandung

Simanjuntak, 1981, Aspek-aspek Sosial, Alumni, Bandung.

Soedjono, D. , 1973, Phatologi Sosial,Alumni, Bandung.
Soerjono Soekanto, Kriminologi Suatu Pengantar, Ghalia Indonesia, Jakarta Indonesia, Cetakan Pertama, 1981.

Peraturan Daerah Kabupaten Badung Nomor 7 Tahun 2016 Tentang Ketertiban Umum dan Ketantraman Masyarakat. 